\title{
Analysis of Soneta Poetry "Senja" by Sanusi Pane
}

\author{
Muhammad Arifin Zaidin ${ }^{1, *}$, Patmawati Halim ${ }^{1}$, Sukirman Nurdjan ${ }^{2}$ \\ ${ }^{1}$ Departement Indonesian Language Education, Open University, Makassar, Indonesia \\ ${ }^{2}$ Departement Indonesian Language Education, State Islamic Religion Institute of Palopo, Palopo, Indonesia
}

Email address:

arifinz@ecampus.ut.ac.id (M. A. Zaidin)

*Corresponding author

\section{To cite this article:}

Muhammad Arifin Zaidin, Patmawati Halim, Sukirman Nurdjan. Analysis of Soneta Poetry "Senja” by Sanusi Pane. International Journal of Literature and Arts. Vol. 8, No. 5, 2020, pp. 277-286. doi: 10.11648/j.ijla.20200805.13

Received: July 28, 2020; Accepted: August 19, 2020; Published: August 27, 2020

\begin{abstract}
This study aims to examine the intrinsic elements of integrated Senja Soneta to form a single unit. The structure of poetry is not just a collection of words that stand alone without cohesion or cohesion because the structure is a whole. Soneta is a lyric poetry written in one stanza (verse) which consists of fourteen lines in total. Intrinsic elements of Soneta, namely diction, style of language, imagination, rhythm-rhyme, repetition of sound, and the relationship between sound and meaning. This research is a descriptive study, the research subject, which is the text of "Senja" Soneta, taken from the 3rd collection of puspa mega poetry published by jaya library in 1975 with standard parameters intrinsically unsettled Sonetas, Data source is Soneta "Senja" by Sanusi Pane with the research instrument is the researcher himself. This research uses purposive sampling. This sample was chosen based on certain considerations. Data collection techniques used to reduce data. The results of this study provide that Sanusi Pane's Senate Soneta poetry uses standard variations, personification language style, semile, parallelism, metaphor, visual image, internal sensation, auditory, tactile, quatraining 1 and 2 abba rhymes, adultery 1 and 2 cde rhymes, alliteration, and tones in adultery 1 and 2. are intrinsic elements that are interconnected and form a unity in forming the stylistic Soneta "Senja", the work of Sanusi Pane). The implication is that it can be considered by the Dean of the Teaching and Education Faculty of the Open University so that Indonesian Sonetas become one of the material in literary theory courses.
\end{abstract}

Keywords: Analysis, Poetry, Structure, "Senja" Soneta, Sanusi Pane

\section{Introduction}

Fifty-four years of Sanusi Pane has passed away, he is in the grave with peace, but his literary works are timeless, his works become quality works in the course of the history of Indonesian literature. A collection of poetrys, namely Puspa Mega. The poetrys in Puspa Mega are almost entirely in the form of Sonetas. One of the poetrys is in the form of a sonata, the "Senja" Soneta, which is a Soneta consisting of 14 lines, generally the first two strophes in the form of four strings and the last two strophes (sect) of three strands. The four strings are usually used by the poet to describe the atmosphere of natural beauty and the third strand is used to show one's own heart so that the whole Soneta is like a poetry consisting of sampiran and content [1].

The main medium of the Senja Soneta is language. A language that has a meaningful sign system. Signs in literary works such as Senja Soneta poetry are inseparable from the first and second layers. The first layer, the process of creating Soneta literary works with words, phrases or sentences selected from the vocabulary of the language. Language plays the first role because with language the creation of the twilight Soneta poetry. Siswantoro mentioned that language is proactive, namely conveying or communicating information [2]. The second tier sign, which is the language of poetry, is subject to the norms or rules of poetry which have different specificities from everyday language.

The language of poetry is arranged according to its conventions such as language style, alliteration, asonance, consonants, rhymes, rhythm, imaging and so on so that the meaning is no longer natural. Macherey explained that in literary works the meaning of language is determined by literary conventions or adjusted to literary conventions [3]. Literature, however, has its own conventions besides the language conventions.

Senja Soneta poetry is a literary product created by Sanusi Pane having a representation of literary functions in favor of 
literature itself and its audience. Horatius, Wellek and Werren, Hall, Abraham, and Soerato stated that the literary function is dulce and utile, didactic-heresy (entertaining and teaching something), used and gratification (useful and satisfying), to teach and delight (giving teachings and giving pleasure), and offering views, goals, hopes and steps to achieve the ideal Indonesian society and nation [4]. The essential existence of poetry refers to the person of the poet, the world in words, the representation of reality, and as something that has the potential to exert a certain influence [5]. The very existence of poetry as mentioned above includes also the essence of Soneta poetry.

The Soneta poetry "Senja" has a romantic friendship with humans and their environment strung with the elements of poetry-building, that is, intrinsic elements. This is important to be expressed so that literary connoisseurs or readers can understand how a Sanusi Pane expresses the Soneta poetry "Senja" in the form of written expressions. One of the proofs of friendship with nature and its surroundings in the expression "Night falls slowly // // Silence of the silent nature now, // Disclosure of the twilight Soneta poetry is one form of curiosity of its literary functions through the analysis of the intrinsic structure attached to the Senja Soneta and this analysis is still lacking by literary researchers. Two things are the focus in the analysis of the intrinsic structure of the twilight Soneta poetry, namely to examine the integrated intrinsic elements to form a single unit and examine how variations or variations of the intrinsic elements that exist in the twilight Soneta poetry. Disclosure of the intrinsic elements and the variety contained in the Senja Soneta poetry used the analysis parameters, namely the second tier sign system or the intrinsic rules of the Senja Soneta poetry element.

The results of Siswantoro's research prove the structure of Soneta's "Regrets" by Ali Hasyimi show that the poetry of Ali Hasymi's Soneta fulfills the intrinsically integrated elements forming a unity and variation or variety of intrinsic elements that exist in Soneta poetry [2]. The Soneta poetrys "Regret" by Ali Hasyimi and "Senja" by Sanusi Pane will have different intrinsic elements. This is what inspires this research.

\section{Literature Review}

Literature review is discussed about the analysis, structure, understanding of Sonetas, structures, intrinsic elements of Sonetas, namely: diction, style of language, imagination, rhythm, rhyme, sound repetition, and the relationship between sound and meaning.

\subsection{Defenition of Analysis}

The word analysis comes from the Greek, namely analyein which means to complete, describe [6]. Furthermore it is stated that the analysis also provides an interpretation (interpretation) of poetry segments on the basis of functions and relationships between segments or intrinsic elements to arrive at an effect. This interpretation will lead a researcher to be able to see the unity of the intrinsic elements being studied and see the capacity (variation) of the intrinsic elements of the analysis of poetry. The structural analysis of an analysis must have literary competence because it is this competence that guides during the surgical analysis process. The task of a reviewer in a structural perspective is to make implicit rules explicit to find the literary effect.

\subsection{Defenition of Structure}

Poetry is an object, because it must be a structure. The term structure in poetry was adopted from the treasures of structural anthropology which was pioneered by Levi-Strauss There is no element that has meaning in itself autonomously, except related to the meaning of all elements in the relevant structural system [7]. Structure means shape or building. Structure means understanding the elements, namely the structure itself [8]. Thus, the structure of poetry is not just a collection of words that stand alone without cohesion or cohesion because the structure is a whole.

Jean Pieget mentions the structure has the whole idea, the structure has the idea of transformation and the structure has the idea of self-regulating [9]. The overall idea is an idea that contains internal cohesiveness among the structure-building elements. The idea of transformation is an idea that is never static because it is open to forming new aspects of the structure, whereas the idea itself is a structure that can stand alone because have intrinsic laws that are transformative to form cohesiveness and produce new aspects Jean Piaget in [10] structure is the order of entities that fundamentally embodies the idea of the whole, transformation, and selfregulation.

\subsection{Defenition of Soneta}

Abrams explain that Soneta is a lyric poetry written in one stanza (verse) which consists entirely of fourteen with iambic pentameter patterns and all of these lines are bound by varied poetic patterns [11]. Soneta usually follows two models, namely the Italian or word model and the British or Shakespeare model. It goes on to say Sonetas consist of two parts, namely one octave consisting of eight lines with abba abba and one testet consisting of 6 lines with cdecde or cdedcd rhymes, two closing lines called capitals that rhyme gg.

\subsection{Intrinsic Element of Soneta}

\subsubsection{Diction}

Dictation (Latin: dictionem (Nom. Dictio), "proverb, expression, word"), in its original meaning, is a choice of vocabulary and style of expression that is different from an author or speaker in a poetry or story, in a general sense, it is the specificity of speech, the art of speaking so that every word is clearly heard and understood in full complexity and extremities, and concerns pronunciation and tone, rather than word choice and style. This is more precisely and is often expressed in terms of complaints, or by the articulation of synonyms (https://en.wikipedia.org/wiki/Diction). Diction 
refers to the linguistic choices the writer makes to effectively convey an idea, point of view, or tell a story. In literature, words used by an author can help build different sounds and styles [12].

Dictation refers to the use of words, namely the accuracy of choosing words to express an idea, thing or item to be mandated and suitability or compatibility in using words [13]. A poet in creating poetry literary works always considers the accuracy and appropriateness of the words he uses. The diction used in expressing artistic ideas in the process of creating poetry must be fulfilled from aspects of the requirements of the creation of a literary work, for example syllables, style of language, imagination, poetry, alliteration, consonants, and rhythm. Thus, the role of diction is very important in the process of creating a literary work of poetry.

The correct choice of diction in a literary work of poetry, namely to carefully distinguish denotations and connotations, words that are almost synonymous, words that are similar in spelling, avoid the creation of own words, beware of the use of foreign endings, distinguish common words and special words, and pay attention to the continuity of diction. The common word refers to the word denotative, which is a difference based on its meaning whether there is an additional meaning or sense value in a word. Common and special words refer to the extent of the scope of meaning they contain.

\subsubsection{Language Style}

Style is defined in terms of domains of language use (for example, choices made by certain authors, in certain genres, or in certain texts). Relatively transparent or opaque styles: transparency implies paraphrasability; opacity implies that the text cannot be adequately paraphrased, and that the interpretation of the text is highly dependent on the creative imagination of the reader [14].

Language style is the ability and expertise to write or use beautiful words [13]. Language style (figures of speech) is a turning motion from the form of everyday expressions or the flow of ideas that are usual to produce an extraordinary effect [15]. J. Thornborrow and S. Wareing interpreted linguistic style is a branch of linguistics that studies the characteristics of the use of different languages in a situational manner, with special abilities to take into account certain choices made by individuals and social groups in their language use [16].

The term style (without specific reference to language) is one that we use so commonly in our daily conversations and writing that it doesn't seem to matter. It often happens naturally tends to take it for granted without asking what that might be intended. Language style is a way of speaking / writing depending on the circumstances of doing so, the person (or person) to whom you speak or write [17]. Language style is the way people use language in communication, can be written or spoken language. Language style actually refers to the choice of linguistic forms to convey social or artistic effects. Style also acts as a set of instructions). Argues that styles not only perform some of the same linguistic features in regional and social dialect differentiation patterns but they also display correlations with other social factors. From Romane's statement above, it is clear that style displays the correlation between social factors and language used by society. This means that people can predict what style they will use in their communication according to the current situation.

The creation of Soneta poetry does not rely solely on the literal meaning but merely the creation of language (figues of speech). With language style, it can enrich meaning so that it can get the desired message intensively. Keraf mentioned a good style of language must contain three elements, namely honesty, courtesy, and attractive [13]. Language is a tool to meet, so the language used must be the honesty joint. Manners are manifested through clarity and brevity. It is interesting to use language style that contains energy to create a sense of joy and pleasure.

\subsubsection{Imagination}

Imagination is an attempt to provide coherence between ideas and actions, to provide a basis for the content of relationships and the creation of categories to understand the world around us. What is imagined defines what we perceive as usual [18].

Pengimaji is a word or arrangement of words that can express sensory, such as vision, hearing, and feeling. The line or stanza seems to contain sound echoes (auditive images), visible objects (visual images), and something that can be felt, touched or touched (tactile images or feelings) [19]. Imaging refers to a mental picture formed as a result of the use of certain words. The image in poetry, which is to give a clear picture, to create a special atmosphere, to make life more vivid in the mind and sensing and also to attract attention and other poetry [20].

\subsubsection{Rhythm and Cascade}

The speech algorithm is remembered even when the word itself is lost to us; but rhythm helps us to recover the mental state where we first heard or read poetry, and then the memory gate is opened and words come to us at once [21].

Slamet Mulyana in [19] rhythm is a conflict of sounds: high / low, long / short /, loud / weak, which plays regularly and repeatedly to form beauty, while rhyme is the repetition of sound in poetry to form musicality or orchestration. With sound repetition, poetry becomes melodious if it is read with attention to the sound symbol. The selection of sounds supports the feelings and mood of the poetry. Rhymes are intermittent sounds, both in poetry lines and at the end of poetry lines [22].

\subsubsection{Sound Repetition}

Alliteration is one of the aural devices in poetic language that utilizes sound patterns and repetition [23]. This can be defined as a consonant or cluster consonant repetition. Whereas in the broader sense it includes repetition of internal word consonants, or sometimes even vowels, this is most often understood as repetition of initial word consonants.

Sound repetition, namely alliteration, consonants, and asonance. Alliteration is a repetition of dead sounds or 
consonants at the initial position of a word, such as repetition of the sound / $\mathrm{k} /$ on the twinkling phrase, sound / $\mathrm{m} /$ on the phrase back and forth. The function of alliteration is to emphasize the meaning of certain words and create a series of sounds or rhymes in musical ones $/ \mathrm{r} /$ in marketing phrases [24].

\subsubsection{The Relationship Between Sound and Meaning}

The special function of poetry, as distinguished from music, is conveying human meaning or experience through sound [25]. The relationship between sound and meaning is related to intensification of meaning. Intensification of meaning is related to the use of a number of individual sounds that have certain meaning qualities that are considered inherent. For example, the sound /i/ has the quality of small meanings, such as, a little, stingy, thin and so on.

\section{Research Methods}

\subsection{Types of Research}

This research is a qualitative descriptive study. Descriptive method can be interpreted as a problem solving procedure that is investigated by describing or describing the state of the subject or object of research at the present time based on facts that appear or as they are [26].

\subsection{Description of Soneta Senja}

Soneta "Senja" is taken from the book Collection of Poetry Puspa Mega by Saneosi Pane, 3rd edition, published by Pustaka jaya, 1975.

\subsection{Research Parameters}

The parameter of Soneta Senja's research is the structure which is the object of study. The standard parameters are the intrinsic elements of Sanusi Pane's Seneta Soneta including: diction, language style, imagination (imaging), rhythm and rhyme, sound repetition, and the relationship between sound and meaning.

\subsection{Research Data and Data Source}

This study uses primary data, namely the text of the Soneta poetry: Senja ", by Sanusi Pane. Primary data is the selected primary data obtained from the source book, while secondary data is data obtained indirectly but still refers to research parameters. Secondary data can be obtained through journals, relevant theories that support primary research data (if needed). The source of research data is taken from the poetry of Soneta Senja by Sanusi Pane as primary data. Secondary data sources are taken from journals, a collection of literary criticisms, theses, theses, and sources related to primary data to strengthen the validation of primary data.

\subsection{Research Sample}

Sampling of the Senja Soneta is done by purposive sampling. The determination of the purposive sample is the determination based on certain considerations and this sample is suitable for qualitative research. In addition to purposive sampling, Senja Soneta poetry prioritizes natural serenity and peace and the gratitude of Divine gifts which is manifested in almost all of his work, both poetry and drama. That is why Sanusi Pane is known as a romantic author.

\subsection{Data Collection}

Data collection activities are the most important part of the research process so the quality of a study is largely determined by the researcher. Data collection is carried out in six steps, namely preparing data sheets, selecting data, providing descriptions, drawing conclusions, validating, and analyzing data.

\section{Results and Discussion}

\subsection{Paraphrasing Poetry Soneta "Senja"}

The Soneta poetry "Senja" records the encounter of the poet's adoration of the beauty of nature and the desires of the soul to establish, admire, make peace, and give thanks for His blessings and gifts. This is where Sanusi Pane with poetry and other literary works play with the beauty of words. He contemplates the glory and splendor and peace of the past He contemplated the peace brought by the natural surroundings. Nature is not only as a symbol, but also as an object of changing his poetrys that humiliate nature. In the poetry "Senja", Sanusi Pane in addition to considering a number of aspects inherent in language. In this connection the reader not only gets the sound configuration that carries meaning, but also gets his potential in causing aesthetic effects, such as rhyme and rhythm.

"Twilight" Soneta poetry tends to be the main thematic tendency which rests on the abstraction of nature and time: // Night falls slowly // Peaceful silence is calm, // Silence of nature is silent now, // Sound of the wind is muffled. This stems from the poet's observation of the natural conditions and the time that surrounded his life. Time and nature are humanitarian problems that are beautifully sung. Sanusi Pane looks at nature happily. Nature, which is an unremarkable source to be enjoyed continuously. Sometimes Sanusi Pane's soul wanders far back in time; he longs for the glories of the glorious past. It also appears in the nature of abstarsksi in the phrase which shows: "Flowers in the garden cover the buds" and the abstraction of time revealed paradoxically: "The night falls slowly". This became the choice of the poet to uncover his poetic experience.

In the Soneta poetry "Senja", the first thing that is felt is the inner collective problem that Sanusi Pane sees, feels, even when dealing with anxiety symbols at some point in his life. On this side of the problem a person can suddenly falter, drift into the shadows that he does not understand or instead become a burden of questions that rule the mind and all of it. As can be seen in the verse: "Silent Sukma is such a terrible thing" and conditions and events like this, "silent sukma" is often interpreted as an existential experience. Then proceed 
with the stanza: "Weak lethargic because prone // Hearts long to look at nature", this makes an experience that gives birth to a variety of anxiety over the series on an awareness that he is part of the mysteries of nature that always leads him to a question mark. romance still flows in the soul of Sanusi Pane in the poetry "Senja".

A Heidegger revealed that poetic language is not just a source of aesthetic enjoyment, but it is full of hidden powers, forces that reveal the world, transform our existence and incised history as the result of wild adventures of semiotics [27]. Including what Sanusi Pane revealed through this bitter verse: "Silence is afraid to wait for the night, // Reminisced that I will be handsome // Will Adinda be bound by custom". Finally poking a love for "Adinda". And love can make simple words so extraordinary. Because of love, it is in the recesses of happiness that is thrilling, but it can also create a terrible disaster. Love is like the wind that comes and can feel its presence or even feel its beauty beyond the beauty of the flower garden. And so is the romance that is played in the soul of the poetry of Sanusi Pane.

\subsection{Diction Analysis}

The diction aspects of the "Senja" Soneta, including language style, imaging, poetry, are not easy but to interpret them requires an in-depth understanding of theoretical concepts. In the "Senja" Soneta diction, the aspects of diction and structure of diction are discussed. Variety of diction is related to formal and informal variations. The formal variety is related to the standard variety, the use of standard vocabulary and speech, while the informal variety is related to the nonstandard variety or using non-standard vocabulary and speech. Relationships between words in forming a certain arrangement as a rhetorical tool, so that figurative figures are associated with ideas Connotatively, words are calculated to be able to give certain effects to the reader.

The "Senja" Soneta is proven to use standard vocabulary. As proof, let's examine all the words in the first quatrain as follows.

(1) Malam turun perlahan-lahan.

(2) Damai sentosa hening tenang,

(3) Sunyi senyap alam sekarang,

(4) Suara angin tertahan-tahan,

The first four quatries above all use formal variations or new vocabulary that is standard or standard. Functionally, formal language in poetry is to present a formal atmosphere that acts as a medium to convey ideas or experiences that are contemplative. The first quatrains of the four strands above are also not numbered so that the resulting effect is really serious or hidmat.

The structure of diction is related to the synonymy analysis in the "Senja" Soneta function to emphasize the meaning of certain words as intended by the poet. The synonym in the Soneta "Senja" is explicitly mentioned, which is silence, calm, quiet, silent, as in the two strands of the Soneta below.

(1) Damai sentosa hening tenang,

(2) Sunyi senyap alam sekarang,

Parera asserts that in the use of language, it is often found the desire of language users to replace one meaning with another word whose meaning is more or less the same as variation or as a feature of freedom of language such as quiet, calm, quiet, silent. The word silence and calm have similar meanings that refer referrals with no sound [17]. Its poetic function, array one intertwines with the second array which emphasizes the meaning that on that night the situation was calm and quiet, quiet and peaceful. Thus, there is the concept of variation in the form of expressions, namely quietness in array one, and quietness in array two.

Synonyms and consonance that refer to repeating the sound of consonants in the final position of construction, such as / ng // in the words of calm silence, silent in array one and array two. The choice of words is based on consideration of the creation of sound (ang) so as to create musical and artistic repetition of sounds.

\subsection{Style Analysis of Language}

Leech, G (2004) explain that language style is a deviation from the form of ordinary expressions or deviations from the general mindset in an effort to obtain a more intense disclosure effect. Style is a matter of choice of words and phrases that are correct and careful. Style is also a matter of verbal patterns of a text as a whole [28]. In the Soneta poetry "Senja" Sanusi Pane uses a style of language that is functionally related to other intrinsic elements to form a complete effect. The style of language used in the "twilight" Soneta poetry is as follows.

\subsubsection{Personification Language Style}

In the study of cognitive metaphors, Lakoff and Johnson defined personification as an ontological metaphor involving cross-domain mapping in which objects or entities are further determined by someone [29]. Personification is another strategy to facilitate understanding by providing abstract processes, ideas, and concepts that are integrated with culture. Personification is a figurative language style that describes inanimate objects or inanimate objects as if they have human characteristics [29].

Personification is a special feature of metaphor, which implies inanimate objects act, act, talk like humans. Let's look at the style of personification in the Senja Soneta lines below.

(1) Malam turun perlahan-lahan.

(2) Suara angin tertahan-tahan,

(3) Burung termenung mengingat suka,

(4) Diam takut menanti malam,

The first array of the first quatrains, (2) the last array of the first quatrains, is depicted at night as if moving down slowly. Likewise the wind seems to convey something with a muffled voice. (3) the third array of second quatrains, and (4) the first array of second adultery, illustrated that when Senja arrives the birds are pensive as if they were human and he is quietly afraid to wait for the night as if he felt agitated like humans when he faced life's problems. The style of personification has the integrity of meaning both in cohesion and coherence which forms an artistic sound. secondly, it is 
illustrated that when Senja arrives the birds are pensive as if they were human and he is quietly afraid to wait for the night as if he feels restless like humans when he faces the problems of life. The style of personification has the integrity of meaning both in cohesion and coherence which forms an artistic sound.

\subsubsection{Simile Language Style}

Simile is the following rhetoric or speech, which consists of a comparison between one item with another item. Similes illustrate an example when something that is figurative in contrast, which is sometimes considered the subtype is used solely for the purpose of a simile in the form of a declaration of similarity of objects, actions or relationships in size, shape, activity, color, and impact, and is more strongly impressed at human mind [30].

Simile has a certain shape. Simili is used to compare nouns with nouns generally followed by something similar to an example of "soul in the body like a bird in a cage", or when verbs or phrases are compared to verbs or phrases, followed by "as", as in the example follows: "This is pencil and paper. I want you to compete as the greatest hero in the race for his life [31].

Simile is an explicit comparison, that is, it directly states something the same as something else so that it requires an explicit effort to show similarity, namely words: like, equal, as, better, like and so on [32]. In the Soneta poetry "Senja" the poet uses one array in a simile style, on adultery 1 array / line 1 as follows.

// Sukma sunyi seperti dahsyat//.

The awesomeness of the silence of the soul that he experiences is very deep, very heavy, very high in remembering the dinda bound by adat. This style of language adds even more meaning to the concrete information that the poet wishes to convey to the reader or connoisseurs of literature.

\subsubsection{Paralelism Language Style}

Parallelism is a style of language that seeks equality in the use of words or phrases that occupy the same function in the same grammatical form [13]. The use of parallelism in Soneta poetry "Senja", can be seen in the following array.

//Damai sentosa hening tenang/Sunyi senyap alam sekarang//

The use of parallelism is a good form to highlight words or groups of words with the same function. Utilization of language style in Soneta poetry "Senja" as a whole (unity) and a variety of language styles is an important part to further emphasize the aesthetic and artistic symbols in Soneta poetrys "Senja".

\subsubsection{Metaphora Language Style}

Metaphors express the idea to refine or sharpen the value of the meaning of a statement by using comparisons. Metaphor is a form of using words or phrases that do not express their true meaning, but rather describe an equation or comparison. This is explained by [13] that metaphors are changes in meaning because of the similarity of properties between two objects. Thus, the style of metaphorical language used by the writer to add strength to a sentence to paint a clear picture through comparison or express contrast or similarity in meaning. In this regard, the following metaphorical style is represented in the Senja Soneta arrays.

//Lalu tidur di dalam duka//, //Dalam sarang rasa dihukum//,

In quatrains 2 arrays / rows 2 and 4 are drawn // then sleep in sorrow //, // in the den of punishment / //. In the strand of quake and array, it is depicted that sleep expresses fatigue that has a closeness of meaning to suffering which means failure or failure to reach a wish or desire. The next array of nests is interpreted as a fairly limited and confined place juxtaposed with the phrase sense of punishment which states the meaning of freedom or bondage. This shows that the placement of metaphorical style by the author is intended to concretize and sharpen the meaning so that the value of taste appears to represent emotion for the reader.

\subsection{Imagination}

Imagination is an effort to provide coherence between ideas, actions, and basic categories of creation to understand the world around what is imagined and what is perceived as usual [18]. As a whole the imagination creates images to manipulate an important role in thinking, which is thought which reproduces the impression so that it can think about what is in the mind [33].

Imagination (imaging) becomes a literary tool in applying reality imagery. This is needed by humans as social beings in dealing with the reality that they encounter every day. The driving force of the imagination strengthens the display of facts in literary works. Factual representation is a literary imagination tool in developing certain thoughts [34]. Imagination or imaging can be in the form of visual, auditive, and tactile. How is the imaging aspect in the Soneta poetry "Senja".

\subsubsection{Visual Type}

Imaging visual type (vision) stimulates the sense of vision so often things that are not visible so as if seen [20].

Visual type imagery appears in the phrase peace tranquility // calm silence, // Silent silence // nature now. The visualization of peace and tranquility is a description of an atmosphere full of beauty, calm, comfort. Likewise, silence and calm, and silence and silence incarnate under the same conditions, that nature is full of beauty, tranquility, awareness, and comfort reinforcing the image of a more comprehensive "Senja" Soneta.

The imaging structure that is built in visualization with the use of personification, simile, and paralism, and metaphor has a unified cohesion while describing the integration of various instrisics that form the harmonization of Soneta poetry "Senja" on the lines 1 and 2 lines. If reading array 2 will be continued with an array of 2 . The aesthetic and artistic effects exude a strong meaning with a quaternary onestringed poetic pattern, namely abba Soneta poetry "Senja", by Sanusi Pane, as in the four-string strings of poetry as 
follows:

(1) Malam turun perlahan-lahan a

(2) Damai sentosa hening tenang $b$

(3) Sunyi senyap alam sekarang b

(4) Suara angin tertahan-tahan a

\subsubsection{Type of Internal Sensation}

Pencitraan tipe sensasi internal ditemukan pada frasa "a

Imaging types of internal sensation are found in the phrase "adinda tied to adat" in the third row of adultery two. This image is characterized by the word sukma, a heart whose existence is in the human body. The use of silent and heartfelt sukma phrases provides an illustration of a calm soul atmosphere and a heart that is intoxicated with love or romance. Sukma who want to unite in the longing and longing of the heart is not limited with time will someone adinda who is bound by customs.

Functionally, the poet manages to choose the right form of expression to describe the physical condition of the I simply. To be more precise, the complete array is as follows.

(1) Sukma sunyi seperti dahsyat,

(2) Hati rindu memandang alam

Thus, this analysis will lead the reader to a conclusion that the poet really has selected a type of sensation of internal sensation in an effort to create sound pairs that are as smooth as possible. It also shows that there is an integral relationship between the imaging elements of the internal sensation type in silent sukma phrases such as the terrible in the beginning line and the phrase the heart longs to look at nature in the last line of adultery poetry 1 .

Another internal sensation of imaging can be found in the silent phrase of fear in adultery 1 array 1 is analogous to the heart. When night falls there is a fear that is silenced in the heart that indicates an anxiety about Adinda being bound by adat. Complete adultery 2 in the following "Senja" Soneta.

(1) Diam takut menanti malam,

(2) Terkenang aku akan rupawan,

(3) Akan adinda diikat adat.

\subsubsection{Auditory Imagery}

Auditory imaging is also very often used by poets. This image is produced by mentioning or describing the sound of sound [20]. Auditory imagery (auditory omagery) is an image relating to the image obtained through the sense of hearing. Such imagery can be generated by mentioning or describing the sound of sound, such as the thunderous boom, the song, etc. The hearing imaging of the Soneta poetry "Senja" can be read in the phrase // The sound of wind is muffled // The hearing image that is raised by the poet is a poetic instrument. to clarify the image of angina. The image of the sound of the wind is a description of the environment or nature that is inseparable from the poetry of the Soneta poetry "Senja", quatrains 1 array 4.

\subsubsection{Tactile Imaging}

Images that can be felt by the skin sense of touch, when we read, listen to poetry or speech and find or listen to some form of diction that brings as if to feel what is presented or promoted. Tactile imaging in the Soneta poetry "Senja" is found in the phrase / Peaceful, quiet, quiet / Silent, silent nature now //. The visual, auditory, and tactile imagery shown in the "Senja" Soneta, is an intrinsic element forming an intrinsic unity and diversity to create the poetry of the "Senja" Soneta poetry.

\subsection{Rhyme Analysis}

In each array inserted sounds are arranged systematically to encourage the reader's power of imagery about the object expressed by the poet. Sound enhancements that build poetry are put in various ways by poets. There are those who place a special sound emphasis at the end of the array, there are also those who place a specific sound at the beginning or end of a word. If we look closely at the poetry pattern of the Soneta poetry "Senja" by Sanusi Pane, the Soneta poetry "Senja" places a distinctive sound at the end of the word with the following rhyme pattern.

(1) Malam turun perlahan-lahan

(2) Damai sentosa hening tenang

(3) Sunyi senyap alam sekarang

(4) Suara angin tertahan-tahan

The role of poetry is not limited to musical elements at the end of a line / array so that poetry sounds beautiful and feels artistic, but more than that it is actually closely related to other internal elements in forming a unified structure. Taxation has the role of binding the lines of each quatrains and insulted in certain units of ideas or events.

To understand the structural contribution related to other elements, a study of poetrys after poetrys of each quatrains and adultery is as follows.

\subsubsection{Analysis of Quatrains Rhymes 1}

Let's look at rhyming patterns in quatrains 1

(1) Malam turun perlahan-lahan a

(2) Damai sentosa hening tenang $b$

(3) Sunyi senyap alam sekarang b

(4) Suara angin tertahan-tahan a

The "Senja" Soneta above is clearly seen that the story told in quatrains 1 is dynamic. Lines (1) and (2) si I explained that when the night fell slowly there was a peaceful and quiet atmosphere. In rows (3) and (4) si I declare that nature or the surrounding environment is in a state of silence and silence in the presence of the muffled angina. Thus, the unified relationship between abba rhyme patterns in quatrains 1 and the plot with the effect of creating dynamic moving events with the bonding sounds of artistic abba end rhymes.

\subsubsection{Analysis of Quatrains Rhymes 2}

Let's look at rhyming patterns in quatrains 2

(1) Bunga di kebun menutup kuntum a

(2) Lalu tidur di dalam duka b

(3) Burung termenung mengingat suka $b$

(4) Dalam sarang rasa dihukum a

In this quatrain 2 the rhyme pattern is still the same as the rhyme pattern in quatrain 1 . The quatrain pattern for quatrains 2 is the continuation of quatrains rhyme 1 , namely 
abba rhymes. In rows (5) and (6) si I illustrate that Flowers in the garden no longer bloom and the sorrow is carried away in his sleep. Then in rows (7) and (8) it is also illustrated that it is not only he who suffers misery but the bird is pensive remembering the likes in the nest feeling punished. The suffering he experiences is the same as that of a bird in a nest as if punished. The point is a coherent relationship between abba rhyme patterns in quatrains 2 and plots with the effect of creating dynamic moving ideas within the bonding sounds of artistic abba rhyme.

\subsubsection{Analysis of Adultery Rhyme Patterns 1}

The pattern of adultery rhymes 1 in the Soneta poetry "Senja" Sanusi Pane can be observed as follows.

(1) Sukma sunyi seperti dahsyat c

(2) Lemah lesu karena rawan d

(3) Hati rindu memandang alam e

The rhyme pattern in adultery 1 is a CDE with different similarities and differences in sound from the previous rhymes. Powerful words with the final sound / at /, different from the word prone to the final sound / an /, as well as natural words with the final sound / am /. The different sounds at the end of each line create the musical harmony of the "Senja" Soneta.

\subsubsection{Analysis of Adultery Rhyme Patterns 2}

The analysis of the adultery rhyme 2 produces the same rhyme as the adultery rhyme 1 . Let's look at the final rhyme pattern in the following lines of adultery 2 .

(1) Diam takut menanti malam c

(2) Terkenang aku akan rupawan d

(3) Akan adinda diikat adat e

The word night with the final sound / am /, is different from the word shapely with the final sound / an /, as well as the custom word with the final sound / at /. The different sounds at the end of each line create the musical harmony of the "Senja" Soneta. It can be concluded that the relationship between the patterns of adultery 1 and 2 adultery has an integral relationship in creating the poetry of a Soneta poetry "Senja" by Sanusi Pane.

\subsection{Sound Repetition Analysis}

Sound repetition is an important tool in composing the language of poetry. The impact that can be obtained by sound repetition is sound suggestion, motion, atmosphere, meaning relationship and expressivity and is used by poets in various ways, namely alliteration methods related to consonant repetition and asonance related to vocal repetition [35].

\subsection{Alliteration Analysis}

Repeating consonant sounds is called alliteration at the initial position of words. Alliteration in the Soneta poetry "Senja" can be seen in the quatrains 1 line 3 on the phrase "// Silent silent nature now //." In Sanusi Pane's "Senja" Soneta poetry there is one line that uses the repeating sound / s /, which is the phrase // silent / silent //. Repetition of consonant sounds / $\mathrm{s} /$ in phrases // silent silence // indicates as intensification of word meanings with musical pronunciation

\subsection{Analysis of the Relationship Between Sound and Meaning}

Perrine [25] states: the special function of poetry, as distinguished from music, is to convey meaning or human experience through sound. Several types of relationships between sound and meaning, such as (1) intensification of meaning through sound, (2) melodic sound and non-melodic sound, and (3) length in meters. The discussion of analysis between sound and meaning is more focused on intensifying meaning.

Intensification of meaning refers to the use of a number of individual sounds that have certain meaning qualities that are considered inherent. For example sound / an / on words / slowly / have qualities where not in a hurry, sound / ng / on words / calm / have quality meanings controlling mood, sounds / at / on words / terrible / have quality meanings of critical atmosphere, gripping, sound / an / on / good-looking / and / at / on the word / custom / have each the quality of the meaning of the lover's face and the quality of strict customary character rules.

\subsection{Speech Tone Analysis}

The tone of speech in literature can be defined as the attitude of the writer to the subject matter, to the reader, and to yourself. Speech tone is an emotional color or meaning color of the author's work is an important element of the whole meaning [25]. The author's tone of speech regarding the subject matter he raised in his work can be emotional, colored, sad, happy, neutral, respectful, mocking, and so on. Understanding the tone of the tone is needed because the reader is dealing with silent text. Text that can have to be turned on with various techniques such as lexical analysis, rhythm and so on.

Tone is the poet's attitude towards the reader in line with the point of view he presents. This might happen because from time to time talking about love with oneself will be different when speaking with others [22]. How Sanusi Pane's attitude towards the reader in the Soneta poetry "Senja", can be read in the following phrase.

(1) Sukma sunyi seperti dahsyat c

(2) Lemah lesu karena rawan d

(3) Hati rindu memandang alam e

From adultery 1 it seems that the poet was sad about the reality he was experiencing. Furthermore, can be read further string of subsequent lines in adultery 2 .

(1) Diam takut menanti malam c

(2) Terkenang aku akan rupawan d

(3) Akan adinda diikat adat e

The poet's attitude becomes even more sad and worried when night falls and it reminds us more of the lover's face that is bound by customs. The results of the tone analysis in the Soneta poetry: Senja "awaken with a harmonious attitude that was born from the poet and has intense dynamics to form 
sound and meaning intact.

\section{Conclusion}

"Senja" Soneta poetry by Sanusi Pane is a quality work because it successfully integrates the intrinsic elements of "Senja" Soneta poetry well and clearly so that it is created with cohesion or unity. The diction used in the "Senja" Soneta is formal or standard variety. The results of the analysis show that the relationship between formal aspects and the idea of solid stories in creating dynamic effects Synonyms and consonance that refers to repetition of consonant sounds in the final position of construction, such as / ng // in quiet words, silent silence on array one and array two. The choice of words is based on the consideration of the creation of sounds (ang), (i), (p) so as to create musical musical repetition.

The style of personification language has the integrity of meaning both in cohesion and coherence which forms an artistic sound. The "Senja" Soneta, besides the poet, utilizes the style of personification language, also utilizes the simile language style, and paralesme language style. Semile language style increasingly adds meaning to the concrete information that the poet wishes to convey to the reader or connoisseurs of literature. The use of parallelism in Soneta poetry "Senja" as a whole (unity) and the variety of linguistic styles is an important part to further emphasize the aesthetic and artistic meaning of Indonesian literary works.

Visual type imagery appears in the phrase peace tranquility // calm silence, // Silent silence // nature now. The visualization of peace and tranquility is a depiction of an atmosphere full of beauty, tranquility, comfort. The imaging structure that is built in visualization by the use of personification, simile, and paralism style has a unified cohesion while at the same time illustrating the integration of various instrisics that form harmonization of the Soneta poetry "Senja" on the lines 1, 2 and 3. calm soul atmosphere and a heart that is intoxicated with love or romance is a representation of the internal sensation of the poet. The auditory image raised by the poet is a poetic tool to clarify the image of angina. Sound imagery of the wind is a picture of the environment or nature that is inseparable from the poetry of the Soneta poetry "Senja", quatrains 1 array 4 . Tactile imaging in the Soneta poetry "Senja" is contained in the phrase / Peaceful silence calm calm / Silent silent nature now $/ /$. The visual, auditory, and tactile imagery shown in the "Senja" Soneta, is an intrinsic element forming an intrinsic unity and diversity to create the poetry of the "Senja" Soneta poetry.

\section{Recommendation}

The results of this study should be taken into consideration by the Dean of FKIP Open University so that Indonesian Soneta poetry becomes one of the discussion material in literary theory courses. new poet writer.

\section{References}

[1] A. Rosidi, Ikhtisar sejarah sastera Indonesia. Dunia Pustaka Jaya, 2018.

[2] A. Siswantoro Sunanda, "Metode Penelitian Sastra." Surakarta: Universitas Muhammadiyah Press, 2004.

[3] P. Macherey and T. Eagleton, Theory of literary production. Routledge, 2006.

[4] S. Endraswara, Metodologi penelitian sastra. Niaga Swadaya, 2008.

[5] A. S. Suminto, "Berkenalan dengan Puisi," Yogyakarta Gama Media, 2008.

[6] C. Carpineto and G. Romano, Concept data analysis: Theory and applications. John Wiley \& Sons, 2004.

[7] C. Foley, "A Review of Claire Botterill's Pottery For Life: A Guide for Beginning Potters and Those with Special Needs," $J$. Vocat. Spec. NEEDS Educ., vol. 24, no. 1, p. 37, 2001.

[8] N. K. Ratna, Antropologi sastra: Peranan unsur-unsur kebudayaan dalam proses kreatif. Pustaka Pelajar, 2011.

[9] K. E. Gade, The Structure of Old Norse" Dróttkvcett" Poetry, vol. 49. Cornell University Press, 2018.

[10] H. T. Faruk, Metode penelitian sastra: sebuah penjelajahan awal. Pustaka Pelajar, 2012.

[11] A. Widayat, "Teori Sastra Jawa," Yogyakarta Kanwa Publ., 2011.

[12] S. R. Powell, "Solving word problems using schemas: A review of the literature," Learn. Disabil. Res. Pract., vol. 26, no. 2, pp. 94-108, 2011.

[13] D. Gorys Keraf, Diksi dan gaya bahasa. Gramedia Pustaka Utama, 2009.

[14] G. N. Leech and M. Short, Style in fiction: A linguistic introduction to English fictional prose, no. 13. Pearson Education, 2007.

[15] S. P. Oakley, "Style and language," Cambridge Companion to Tacitus, pp. 195-211, 2009.

[16] J. Thornborrow and S. Wareing, Patterns in language: An introduction to language and literary style. Psychology Press, 1998.

[17] J. D. Parera, Teori semantik. Erlangga, 2004.

[18] Y. Kanu, Curriculum as cultural practice: Postcolonial imaginations. University of Toronto Press, 2006.

[19] H. J. Waluyo, Apresiasi puisi: panduan untuk pelajar dan mahasiswa. Gramedia Pustaka Utama, 2002.

[20] R. D. Pradopo, "Pengkajian Puisi (Analisis Struktural dan Semiotik)," Yogyakarta Fak. Sastra UGM, 2007.

[21] D. Vanderbeke, "Rhymes without reason? or: The improbable evolution of poetry," Polit. Cult., vol. 1, 2010.

[22] M. P. Aminudddin and H. Suryana, Pengantar apresiasi karya sastra. PT Sinar Baru Algensindo, 2000. 
[23] M. Kaneko, "Alliteration in sign language poetry," in Alliteration in culture, Springer, 2011, pp. 231-246.

[24] R. Sutton-Spence, J. Mesch, and M. Kaneko, "Signed Renga: Exploration of "Genre'in Creative Sign Language," in Presentation at the $33 \mathrm{rd}$ annual conference of the German Linguistic Society (DGfS), Georg August University, Göttingen, 2011.

[25] L. Perrine and T. R. Arp, Literature: structure, sound, and sense. Harcourt Brace Jovanovich, 1974.

[26] H. Nawawi, Metode penelitian bidang sosial. Gadjah Mada University Press, 1993.

[27] A. Teeuw, Tergantung pada kata: sepuluh sajak Indonesia. Pustaka Jaya, 1980.

[28] J. Haynes, Style. Routledge, 2006.
[29] A. G. Dorst, "Personification in discourse: Linguistic forms, conceptual structures and communicative functions," Lang. Lit., vol. 20, no. 2, pp. 113-135, 2011.

[30] J. Devlin, How to speak and write correctly. Lulu. com, 2016.

[31] Z. S. Harris, "Discourse analysis," in Papers on syntax, Springer, 1981, pp. 107-142.

[32] M. Israel, J. R. Harding, and V. Tobin, “On simile," Lang. Cult. mind, vol. 100, 2004.

[33] M. Warnock, Imagination. Univ of California Press, 1976.

[34] S. K. Septiawan, "Metode Penelitian Kualitatif." Edisi Kedua, Yayasan Obor Indonesia, Yogyakarta, 2010.

[35] M. Hiraga, "Iconic Meanings of Visual Repetition in Poetry," Semiotics, pp. 95-105, 1991. 